\title{
PENINGKATAN KEMAMPUAN PEMECAHAN MASALAH SISWA MENGGUNAKAN MODEL PEMBELAJARAN TREFFINGER
}

\author{
Lisa Juanti1 ${ }^{\text {, Budi Santoso }}{ }^{2}$ \& Cecil Hiltrimartin ${ }^{3}$ \\ ${ }^{123}$ Universitas Sriwijaya, Sumatera Selatan, Indonesia \\ lisajuantii@gmail.com
}

\begin{abstract}
Abstrak
Penelitian ini bertujuan untuk mengetahui bagaimana meningkatkan kemampuan pemecahan masalah siswa menggunakan model pembelajaran Treffinger pada pembelajaran matematika. Penelitian ini merupakan jenis penelitian deskriptif. Subjek dalam penelitian ini adalah siswa kelas VIII.7 SMP Negeri 9 Palembang dengan jumlah siswa 30 orang. Pengambilan data proses pembelajaran dilakukan dengan menggunakan observasi dan pengambilan data kemampuan pemecahan masalah siswa dan dilakukan dengan menggunakan tes. Data yang digunakan dalam penelitian ini adalah data hasil kemampuan pemecahanan masalah setelah mengerjakan soal tes untuk mengukur kemampuan pemecahan masalah siswa. Soal tes diberikan setelah proses pembelajaran dan mengacu pada indikator kemampuan pemecahan masalah. Berdasarkan hasil penelitian disimpulkan bahwa melalui model pembelajaran Treffinger kemampuan pemecahan masalah siswa dengan nilai minimal 80 pada tes dikategorikan baik dengan persentase siswa sebesar $86.67 \%$.
\end{abstract}

Kata kunci : Model Pembelajaran, Treffinger, Kemampuan Pemecahan Masalah Siswa

\begin{abstract}
The current research intends to clarify how Treffinger learning model improves student problem-solving skill on school mathematics subject. This research is a descriptive study. There are 30 students as the subjects and are taken from the eighth-grade students of SMPN 9 Palembang South Sumatra. The data are obtained from teaching and learning observation and student test. Based on the analysis, it is found that through Trefinger model the students whose scores are minimally 80 at the test is categorized as good skill in problem solving which is around $86.67 \%$ of students.
\end{abstract}

Keywords: Learning Model, Treffinger, Student Problem Solving Skills 
Juanti, L., Santoso, B., \& Hiltrimartin, C. (2016). PENINGKATAN KEMAMPUAN PEMECAHAN MASALAH SISWA MENGGUNAKAN MODEL PEMBELAJARAN TREFFINGER. JURNAL TATSQIF, 14(2). Retrieved from http://ejurnal.iainmataram.ac.id/index.php/tatsqif/article/view/1072

\section{PENDAHULUAN}

Matematika merupakan suatu ilmu yang mendasari perkembangan teknologi modern, mempunyai peran yang penting dalam berbagai disiplin ilmu dan memajukan daya pikir manusia (Depdiknas, 2008). Berdasarkan Peraturan Menteri no 22 tahun 2006, ditetapkan salah satu tujuan pelajaran matematika agar peserta didik memiliki kemampuan memecahkan masalah meliputi memahami masalah, merancang model matematika, menyelesaikan model dan menafsirkan solusi yang diperoleh. Demikian pula, tujuan yang diharapkan dalam pembelajaran matematika oleh National Council of Teachers of Mathematics (NCTM, 2000). National Council of Teachers of Mathematics (2000) menetapkan lima standar kemampuan matematis yang harus dimiliki oleh siswa, yaitu kemampuan pemecahan masalah (problem solving), kemampuan komunikasi (communication), kemampuan koneksi (connection), kemampuan penalaran (reasoning), dan kemampuan representasi (representasi).

Menurut penelitian yang dilakukan Yuanari (2011), rendahnya kemampuan pemecahan masalah siswa dikarenakan masih banyaknya siswa yang kurang aktif dalam pembelajaran matematika di kelas maupun dalam mengerjakan soal matematika. Penelitian lain yang dilakukan oleh Ekawati (2010) bahwa peserta didik hanya menghapal konsep dan kurang mampu mengunakan konsep tersebut jika menemui masalah dalam kehidupan nyata yang berhubungan dengan konsep yang dimiliki. Lebih jauh lagi bahkan peserta didik kurang mampu menentukan masalah dan merumuskannya, sehingga mereka mengalami kesulitan dalam memecahkan masalah matematika. Kesulitan peserta didik dalam memecahkan masalah matematika sangat mempengaruhi hasil yang dicapai oleh peserta didik. Karena dalam pembelajaran matematika tidak hanya diperlukan pengetahuan mengenai konsep saja, melainkan harus dengan penguasaan dan keterampilan peserta didik dalam menyelesaikan masalah matematika. Sejalan dengan Anggraini (2010) mengatakan siswa terbiasa mengerjakan 
soal-soal non-rutin yang membuat siswa tidak dapat memecahkan suatu masalah apabila diberikan soal-soal bentuk non-rutin. Mereka tidak terbiasa untuk memecahkan suatu masalah secara bebas dan mencari solusi dengan cara mereka sendiri. Mereka hanya bisa mengerjakan soal yang bentuknya sama dengan contoh soal yang diberikan guru.

Kenyataan di atas juga sejalan dengan hasil observasi pada salah satu kelas VIII di SMP Negeri 9 Palembang, ketika siswa diberikan soal uraian yang sesuai dengan kemampuan pemecahan masalah siswa, dari permasalahan yang diberikan didapat 6 orang siswa (20\%) mengerjakan satu soal dengan benar dari tiga soal yang diberikan, 14 orang siswa (46,46\%) siswa mengerjakan dua soal dengan benar dari tiga soal dan 10 orang siswa (33\%) siswa yang bisa mengerjakan ketiga soal dengan benar. Dari uraian di atas dapat dikatakan kemampuan pemecahan matematik siswa belum memuaskan.

Untuk mencapai tujuan pembelajaran matematika yang salah satunya adalah kemampuan pemecahan masalah, maka diperlukan model pembelajaran yang tidak hanya menstrasfer pengetahuan kepada siswa tetapi mampu merangsang daya pikir siswa untuk membentuk pengetahuan mereka sendiri dalam memecahkan masalah-masalah matematika yang dihadapinya. Salah satu model pembelajaran yang dapat diterapkan adalah model pembelajaran Treffinger. Model pembelajaran Treffinger adalah suatu model yang membangkitkan belajar kreatif. Treffinger (1980) mengusulkan model pembelajaran yang praktis untuk menggambarkan tiga tingkat yang berbeda dari pembelajaran yang kreatif, dengan pertimbangan kedua dimensi kognitif dan afektif pada setiap tingkat. Pomalato (2005:23) juga menyatakan Treffinger ini adalah upaya dalam mengintegrasikan dimensi kognitif dan afektif siswa untuk mencari arah-arah penyelesaian yang akan ditempuhnya untuk memecahkan permasalahan yang merupakan karakteristik yang paling dominan dari model pembelajaran Treffinger serta terdiri dari tiga tahapan penting, yaitu 1) tahap pengembangan fungsi 
divergen merupakan tahap basic tool 2) tahap pengembangan berfikir dan merasakan lebih kompleks merupakan tahap practise with process, serta 3) tahap pengembangan keterlibatan dalam tantangan nyata merupakan tahap working with real problem. Teknik-teknik tahap pertama antara lain menggunakan teknik pemanasan, pemikiran dan perasaan terbuka, sumbang saran, dan penangguhan kitik, daftar penulisan gagasan, penyusunan bersifat, dan hubungan yang dipaksakan. Teknik-teknik kreatif tingkat kedua meliputi antara lain, teknik analisis morfologis, dan sosio drama serta sinetic. Teknik-teknik kreatif tingkat ketiga menggunakan teknik pemecahan masalah secara kreatif. Dengan demikian pembelajaran dengan menggunakan model Treffinger diharapkan dapat menumbuhkan dan meningkatkan kemampuan pemecahan masalah matematika siswa, mengarahkan siswa untuk berpikir secara logis tentang hubungan antar konsep dan situasi dalam permasalahan yang diberikan serta menghargai keragaman berpikir yang timbul selama proses pemecahan masalah berlangsung.

Berdasarkan uraian di atas serta mempertimbangkan bahwa Treffinger belum pernah diterapkan di SMP Negeri 9 Palembang, maka penulis tertarik untuk melakukan penelitian dengan rumusan pertanyaan penelitian sebagai berikut: "Bagaimana meningkatkan kemampuan pemecahan masalah siswa menggunakan model pembelajaran Treffinger pada pembelajaran matematika?"

\section{METODE}

Penelitian ini merupakan penelitian deskriptif. Subjek penelitian dalam penelitian ini adalah siswa kelas VIII.7 SMP Negeri 9 Palembang dengan siswa sebanyak 30 orang terdiri dari 13 orang laki-laki dan 17 orang perempuan. Adapun prosedur atau tahapan yang akan dilaksanakan adalah sebagai berikut penelitian ini adalah sebagai berikut:

\section{Tahap Persiapan}


Pada tahap persiapan yang dilakukan oleh peneliti meliputi : (1) Membuat rencana pelaksanaan pembelajaran (RPP) disesuaikan dengan model pembelajaran matematika Treffinger; (2) membuat media pembelajaran berupa Lembar Aktivitas Siswa (LAS); (3) membuat instrumen penilaian berupa soal pemecahan masalah sebagai soal tes; (4) menguji validitas instrumen penilaian.

\section{Tahap Pelaksanaan}

Langkah-langkah pada tahap pelaksanaan dengan model pembelajaran Treffinger meliputi

Pendahuluan : (1) Guru menyampaikan tujuan pembelajaran yang ingin dicapai setelah pembelajaran dan menjelaskan alur kegiatan yang akan dilakukan; (2) guru memberikan apersepsi kepada siswa mengenai materi pelajaran yang sudah diberikan; (3) siswa dibagi menjadi 6 kelompok, masing-masing tiap kelompok terdiri dari 5 orang; (4) guru membagikan lembar kerja siswa (LAS) yang menyampaikan situasi yang ada pada LAS secara umum.

Kegiatan Inti Basic Tool (Tahap I) : (1) masing-masing siswa ditiaptiap kelompok saling berdiskusi mengidentifikasi masalah pertama yang diberikan yang merupakan permasalahan terbuka; (2) selama berdiskusi siswa mengungkapkan dan menuliskan gagasan atau idenya untuk menyelesaikan permasalahan yang diberikan; (3) guru membimbing siswa siswa selama melakukan diskusi; (4) setelah melakukan diskusi, guru mempersilahkan perwakilan kelompok untuk mempresentasikan hasil diskusi dari kelompok; (5) Kelompok yang lain diminta untuk menanggapi, melengkapi hasil dari kelompok yang mepresentasikan, (6) guru meluruskan atau membantu siswa memberi penjelasan ketika terdapat penyelesaian yang berbeda dari hasil diskusi siswa.

Practise With Process (Tahap II) : (1) masing-masing siswa ditiap-tiap kelompok kembali berdiskusi mengidentifikasi masalah kedua yang 
diberikan yang merupakan soal yang complicated; (2) Selama berdiskusi siswa saling mengungkapkan dan menuliskan gagasan atau idenya untuk mencari penyelesaian permasalahan yang paling tepat; (3) guru membimbing siswa selama melakukan diskusi; (4) setelah melakukan diskusi, guru mempersilahkan perwakilan kelompok untuk mempresentasikan hasil diskusi dari kelompok; (5) kelompok yang lain diminta untuk menanggapi, melengkapi hasil dari kelompok yang mempresentasikan, (6) guru meluruskan atau membantu siswa memberi penjelasan ketika terdapat penyelesaian yang berbeda dari hasil diskusi siswa.

Working With Real Problem (Tahap III) : (1) masing-masing siswa ditiap-tiap kelompok kembali berdiskusi mengidentifikasi masalah ketiga yang diberikan yang merupakan soal yang ada dikehidupan sehari-hari; (2) selama berdiskusi siswa saling mengungkapkan dan menuliskan gagasan atau idenya untuk mencari penyelesaian permasalahan yang paling tepat (3) guru membimbing siswa selama melakukan diskusi; (4) setelah melakukan diskusi, guru mempersilahkan perwakilan kelompok untuk mempresentasikan hasil diskusi dari kelompok; (5) kelompok yang lain diminta untuk menanggapi, melengkapi hasil dari kelompok yang mempresentasikan; (6) guru meluruskan atau membantu siswa memberi penjelasan ketika terdapat penyelesaian yang berbeda dari hasil diskusi siswa.

\section{Kegiatan Penutup}

Kegiatan ini meliputi : (1) guru membimbing siswa merangkum pembelajaran pada hari itu; (2) guru menginformasikan kegiatan untuk pertemuan selanjutnya.

Dalam penelitian ini teknik pengumpulan data kemampuan pemecahan masalah siswa yang digunakan adalah tes tertulis yang berbentuk soal essay. Tes dilakukan pada pertemuan keempat. Data mengenai kemampuan pemecahan masalah siswa melalui soal-soal 
pemecahan masalah diperiksa dengan mengoreksi lembar jawaban siswa, kemudian dianalisis untuk melihat kemampuan pemecahan masalah siswa menyelesaikan soal-soal pemecahan masalah.

\section{HASIL DAN PEMBAHASAN}

\section{Deskripsi Hasil Pelaksanaan Pembelajaran}

Penerapan model pembelajaran Treffinger dilakukan dikelas VIII.7 dengan menggunakan instrumen yang telah divalidasi sebelumnya. Selama melakukan penelitian, peneliti didampingi oleh guru mata pelajaran dan tiga orang observer. Observasi dilakukan sebanyak tiga kali pertemuan dengan jumlah siswa pada tiap pertemuan 30 orang siswa.

Pada pertemuan pertama, kedua dan ketiga peneliti menerapkan pembelajaran model Treffinger dengan menggunakan LAS. Dari hasil analisis pengerjaan LAS yang dilakukan siswa secara berkelompok, siswa sudah mampu menylesaikan permasalahan yang ada pada LAS sesuai dengan langkah-langkah. Namun masih ada kekurangan dari jawaban siswa. Untuk mengetahui deskripsi kegiatan siswa, peneliti mengambil contoh kegiatan siswa pada pertemuan pertama.

Proses pembelajaran untuk pertemuan pertama dilaksanakan pada tanggal 18 Mei 2015, diikuti oleh 30 siswa dengan alokasi waktu 2 x 40 menit. Kegiatan yang dilakukan adalah menentukan peluang suatu kejadian dengan cara diskusi kelompok, dengan tahap-tahap model pembelajaran Treffinger sebagai berikut :

a. Basic Tool

Pada tahap basic tool, guru memberikan permasalahan berupa masalah terbuka yang terdapat pada LAS kepada siswa dan meminta tiap kelompok untuk berdiskusi mencari penyelesaian permasalahan tersebut. Siswa diminta untuk menentukan peluang masing-masing spinner, menentukan spinner yang tepat dan alasan 
dalam pemilihan spinner. Kemudian setiap anggota kelompok akan saling berdiskusi dan saling mengeluarkan pendapat tanpa takut pendapat yang disampaikan benar atau salah. Pada tahap ini siswa mulai berdiskusi dan saling bertanya kepada masing-masing anggota kelompok. Guru mengamati pekerjaan siswa dan ingin mengetahui langkah mana yang membuat siswa mengalami kesulitan dan guu memberikan bimbingan dengan cara menggali informasi siswa itu sendiri.

Jika dilihat dari jawaban siswa diatas, terlihat siswa sudah bisa mengikuti tahap pertama pada model Treffinger. Siswa sudah memiliki kesediaan ntuk menjawab permasalahan mulai dari mengidentifikasi terlebih dahulu unsur-unsur yang diketahui dan ditanyakan. Siswa juga sudah berani mengambil resiko terlihat dari perencanaan dalam menyelesaikan masalah dan menyelesaikan masalah yang sebelumnya melalui proses rasa ingin tahu siswa yaitu pada saat siswa saling bertanya dan menjawab dengan gagasan masing-masing dalam menentukan ruang sampel dari permasalahan tersebut.

Dari hasil pengamatan, hampir seluruh kelompok dapat menyelesaikan permasalahan pertama yaitu menentukan peluang masing-masing spinner, tetapi ada satu kelompok yang masih bingung pada langkah merencanakan penyelesaian yaitu kelompok Anjar. Pada permasalahan ini kelompok ini bingung menentukan Ruang Sampel dan cara menyajikan kemungkinan karena mereka masih teringat dengan contoh soal yang menyajikan kemungkinan dengan menggunakan diagram pohon sehingga ketika diberikan permasalahan ini mereka bingung. Pada tahap pertama ini seluruh siswa belum melakukan pengecekan kembali dan belum terbiasa sehingga guru menjelaskan kembali langkah-langkah yang harus dilakukan oleh siswa. 


\section{b. $\quad$ Practise with Process}

Setelah menyelesaikan permasalah yang ada pada tahap pertama, siswa diberikan permasalahan kedua yang lebih rumit dari tahap pertama. Pada tahap ini siswa akan menerapkan bagaimana menentukan peluang dari rumus peluang yang telah mereka ketahui dan penggunaan pengetahuan yang ada dalam menyelesaikan masalah yang diberikan. Permasalahan kedua siswa akan menentukan peluang jumlah 3 angka dari 5 angka yang tersedia dan jumlah 3 angka tersebut habis dibagi 3. Pada tahap ini siswa mulai menunjukkan kemampuan menyelesaikan masalah, menganalisis masalah, menggunakan dan memadukan pengetahuan sebelumnya untuk menyelesaikan masalah. Dari lembar jawaban siswa suah bisa mendeskripsikan masalah yaitu mengidentikasi apa yang diketahui dan ditanyakan dari soal, menerapkan dan memadukan penyelesaian dengan pengetahuan sebelumnya. Pada lembar jawaban siswa diatas pada tahan perencanaan siswa menggunakan pohon faktor kemudian untuk menyelesaikan permasalahan siswa membagi jumlah ketiga angka dengan asumsi ketiga angka tersebut boleh berulang. Pada langkah merencanakan penyelesaian masalah ada beberapa kelompok menggunakan penyelesaian yang berbeda. Kelompok Dite, Anjar, Amin, dan Nyimas mereka menyelesaikan dengan cara menjumlahkan langsung ketiga angka dan tanpa pengulangan kemudian dibagi 3. Untuk kelompok khairani mereka menggunakan diagram pohon kemudian menjumlahkan ketiga angka tersebut lalu dibagi 3. Sedangkan kelompok Diana mengalami masalah, pada langkah merencanakan dan menyelesaikan masalah, mereka tidak menjumlahkan ketiga angka tetapi langsung mengambil satu angka dan dibagi 3.

c. Working with Real Problem 
Pada tahap terakhir, siswa diberikan dengan soal yang berhubungan dengan kehidupan sehari-hari dengan konteks acara kuis di televisi. Siswa akan menentukan peluang meraih hadiah disebuah acara kuis. Setiap anggota kelompok akan mulai berdiskusi dan mulai mengelola kemampuannya dengan keterlibatan-keterlibatan dalam masalah sehari-hari dan mampu menentukan sendiri langkah-langkah menyelesaikan masalah. Pada permasalahan tahap terakhir beberapa kelompok mengelami kesulitan untuk merencanakan masalah walaupun sudah diberi bantuan pada LAS tersebut, akan tetapi setelah dijelaskan kembali siswa sudah mulai mengerti dan mencoba mencari penyelesaian dari permasalahan ini. Pada lembar jawaban siswa sudah bisa menerapkan konsep yang telah dipelajari pada permasalahan di tahap ketiga.

\section{Deskripsi Hasil Tes}

Analisis data tes kemampuan pemecahan masalah siswa diperoleh dari soal-soal tes yang diberikan pada pertemuan terakhir tanggal 30 Mei 2015 diikuti oleh 30 siswa setelah melakukan pembelajaran matematika menggunakan model Treffinger sebanyak 3 kali dengan media pembelajaran LAS. Soal tes berupa soal essay, yang soal pertama berkaitan dengan peluang dari 4 buah uang logam, soal kedua berkaitan peluang pengambilan bola yang diberi nomor dan soal ketiga be rkaitan dengan peluang terbesar pemain yang menang dalam sebuah permainan. Peneliti meminta siswa mengerjakannya secara individu selama 70 menit. Soal tes yang diberikan diharapakan dapat diselesaikan oleh siswa dengan menerapkan yang sudah mereka dapatkan saat mengikuti 3 pertemuan sebelumnya.

Setelah tes selesai, peneliti memeriksa dan menganalisis jawaban siswa untuk memperoleh data tentang kemampuan pemecahan masalah siswa. Berikut adalah cara peneliti menganalisis 
hasil tes siswa mengacu pada 4 indikator kemampuan pemecahan masalah :

Soal no.1: $\quad$ Jika 4 koin dilempar, berapakah peluang bahwa paling sedikit 2 angka muncul!

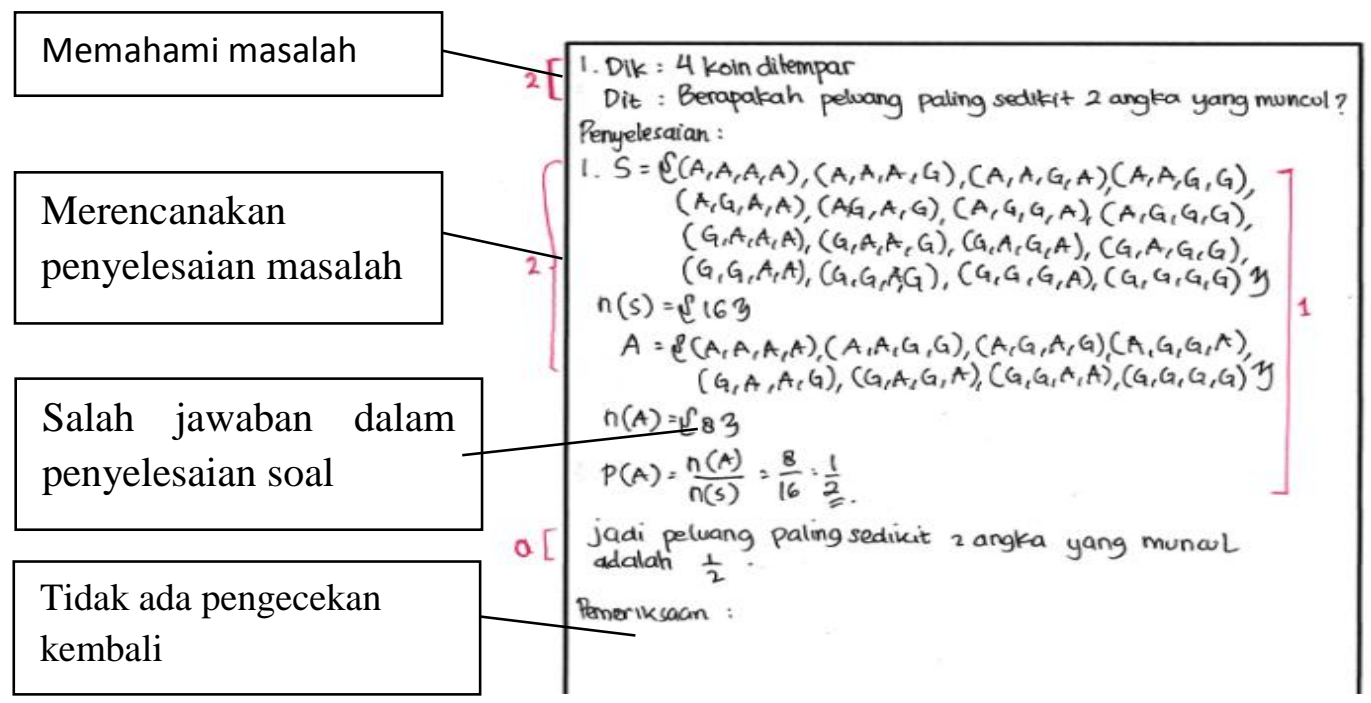

Gambar 1

Analisis Jawaban Siswa Pada Soal Nomor 1

Pada lembar jawaban di atas, untuk soal nomor 1 siswa hanya mendapatkan skor 5. Keempat indikator kemampuan pemecahan masalah siswa belum muncul sepenuhnya. Pada indikator memahami masalah terlihat dari jawaban siswa tersebut menuliskan kembali apa yang diketahui dan ditanya pada soal. Pada indikator merencanakan penyelesaian masalah masih terdapat kesalahan pada lembar jawaban siswa, siswa sudah merencanakan pnyelesaian akan tetapi terdapat kekeliruan dalam merencanakan penyelesaian sehingga pada indikator menerapkan rencana penyelesaian juga terdapat kesalahan. Untuk indikator memeriksa kembali juga siswa tidak melakukan pemeriksaan sehingga dari lembar jawaban siswa ini terlihat dalam penyelesaiannya siswa belum memahami dan mengerti apa yang diinginkan oleh soal. 
Selanjutnya untuk soal nomor dua, skor maksimum jika keempat indikator kemampuan pemecahan masalah muncul dengan tepat adalah 10.

Soal nomor dua

"Dalam suatu kotak terdapat 100 bola serupa yang diberi nomor 1,2,...100. Apabila dipilih satu bola secara acak, maka peluang terambilnya bola dengan nomor yang habis dibagi 5, tetapi tidak habis dibagi 3 adalah

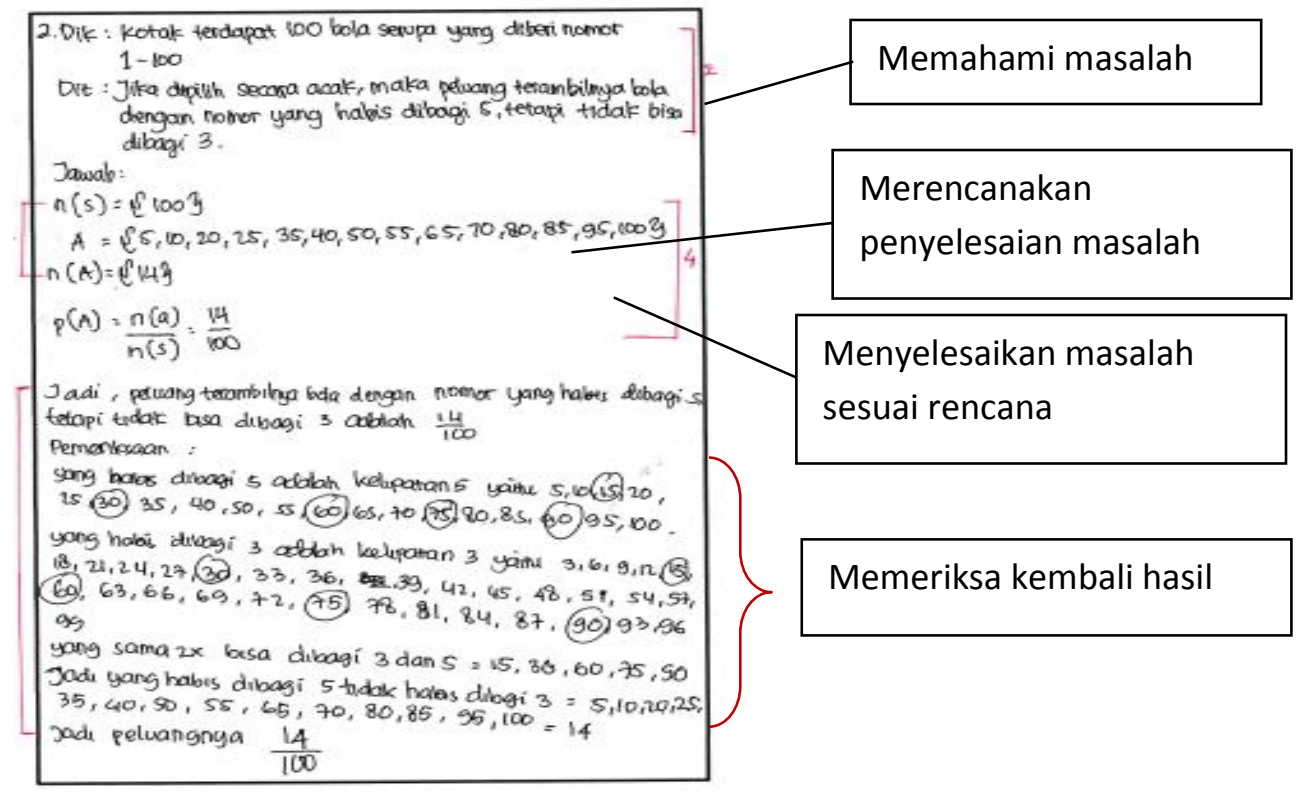

Gambar 2

Analisis Jawaban Siswa pada Soal Nomor 2

Pada jawaban diatas, untuk soal nomor dua sisa tersebut mendapatkan skor 10. Keempat indikator kemampuan pemecahan masalah siswa sudah muncul. Mulai dari indikator memahami masalah terlihat dari jawaban siswa tersebut dengan menuliskan kembali apa yang diketahui dan ditanyakan dari soal. Siswa sudah melakukan indikator merencanakan penyelesaian masalah dengan menuliskan model dan pemilihan strategi, kemudian pada indikator menyelesaikan masalah siswa mendapatkan hasil yang tepat dikarenakan penyelesaian masalah sesuai dengan rencana yang telah dipilih. Pada indikator 
memeriksa kembali terlihat pada lembar jawaban siswa, siswa melakukan pengecekan untuk memeriksa kembali hasil yang telah diperoleh. Karena semua indikator muncul dan sesuai dengan jawaban yang diminta, maka siswa tersebut memperoleh skor 10.

Kemudian untuk soal nomor tiga, skor maksimum jika ketiga indikator kemampuan pemecahan masalah muncul dengan tepat adalah 10.

Soal nomor tiga

"Andi, Budi, dan Cecil bermain dengan menggunakan dua buah dadu yang dilambungkan secara bersamaan. Aturan pemberian skor ditentukan oleh jumlah dua mata dadu yang keluar, yaitu sebagai berikut:

- Jika jumlahnya adalah salah satu unsur barisan Fibonancci $\{1,1,2,3,5,8,13, \ldots\}$ maka Andi mendapatkan 1 poin.

- Jika jumlahnya adalah bilangan prima maka Budi mendapatkan 1 poin.

- $\quad$ jika tidak terjadi keduanya, Cecil mendapat 1 poin.

Pemain yang mendapatkan poin 20 pertama kali memenangkan permainan tersebut. Siapakah pemain yang berpeluang besar memenangkan permainan tersebut?"

Indikator memahami masalah adalah siswa dapat menulis kembali apa yang diketahui dari soal dan yang ditanyakan dari soal. Indikator merencanakan penyelesaian, terlihat siswa membuat tabel untuk mendapatkan penyelesaian dari soal, kemudian siswa melanjutkan ke indikator menyelesaikan masalah sesuai dengan rencana yaitu siswa mulai perhitungan sesuai dengan rencana yang telah diterapkan untuk mendapatkan hasil akhir. Pada indikator terakhir siswa menjelaskan kembali hasil yang telah didapatkan. Dengan demikian skor yang diperoleh siswa adalah 10. 


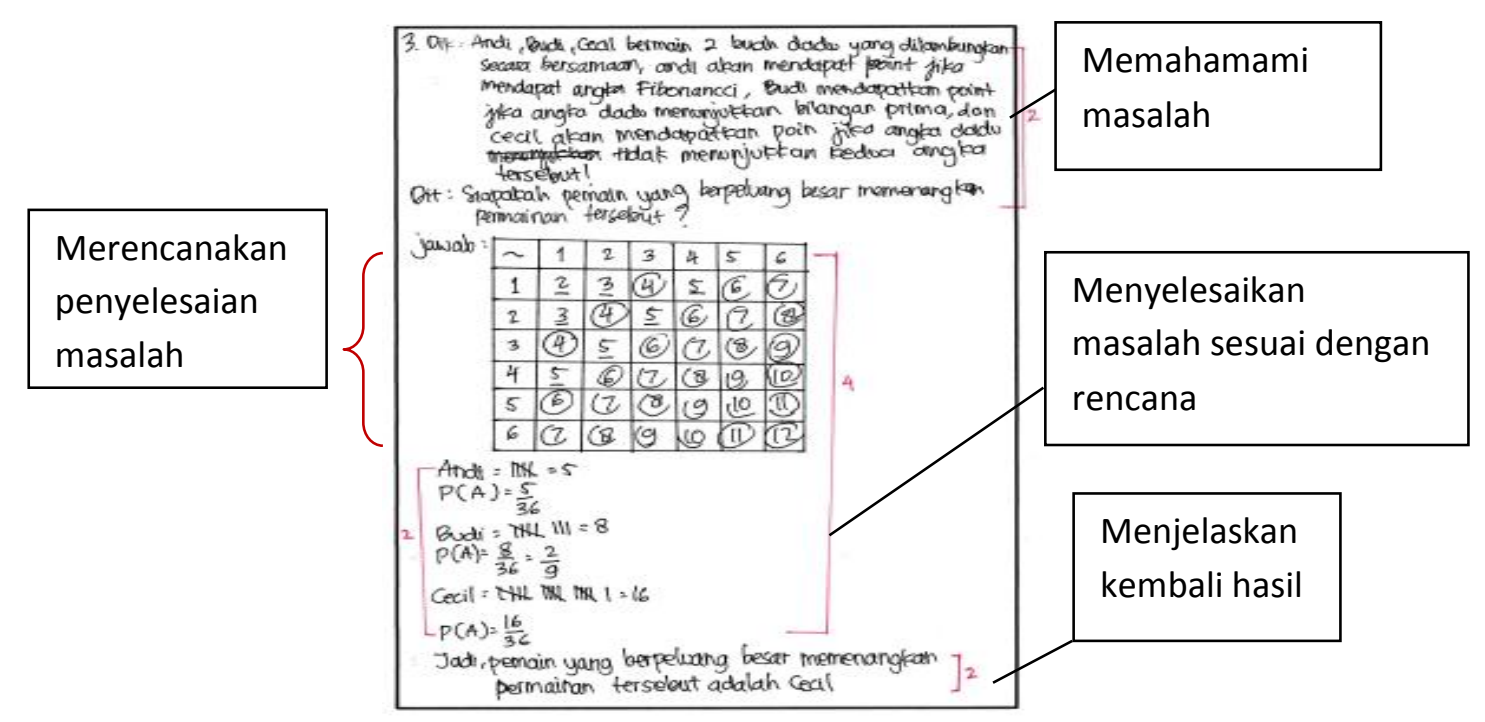

Gambar 3

Analasis Jawaban Siswa Terhadap Soal Nomor 3

Data hasil tes kemampuan pemecahan masalah siswa diperoleh dari lembar jawaban siswa yang dilaksanakan pada pertemuan keempat, yang kemudian dianalisis untuk melihat kemampuan pemecahan masalah siswa. Adapun kemampuan pemecahan masalah siswa setelah dianalisis dan dikonversikan dapat dilihat pada tabel berikut :

Tabel 1

Distribusi Frekuensi Kemampuan Pemecahan Masalah Siswa dengan

Pembelajaran Model Treffinger

\begin{tabular}{|c|c|c|c|}
\hline \multirow{2}{*}{ Nilai } & \multicolumn{2}{|c|}{ Tes } & \multirow{2}{*}{ Kategori } \\
\cline { 2 - 3 } & Frekuensi & \% & \\
\hline $91-100$ & 6 & $16,67 \%$ & Sangat Baik \\
\hline $80-90$ & 20 & $70 \%$ & Baik \\
\hline $55-79$ & 4 & $13,3 \%$ & Kurang \\
\hline $0-55$ & 0 & $0 \%$ & Sangat Kurang \\
\hline $\begin{array}{c}\text { Nilai } \\
\text { Rata-Rata }\end{array}$ & \multicolumn{2}{|c|}{82,39} & \\
\hline \multicolumn{3}{|c|}{} \\
\hline
\end{tabular}


Dari tabel diatas dapat dilihat bahwa rata-rata kemampuan pemecahan masalah siswa dalam pembelajaran dengan menggunakan model Treffinger berkategori baik. Dengan demikian nilai rata-rata tes terhadap kemampuan pemecahan masalah siswa kelas VIII.7 SMP Negeri 9 Palembang sebesar 82,39 yang dikategoikan baik.

\section{Pembahasan}

a. Model Pembelajaran Trefffinger

Dari tiga pertemuan pembelajaran menggunakan model pembelajaran Treffinger ketiga tahap pembelajaran Treffinger pada pembelajaran pada pertemuan pertama sampai pertemuan ketiga kemampuan mengaplikasikan konsep atau logaritma dalam pemecahan masalah mulai terlihat saat siswa menyelesaikan masalah terbuka, soal diskusi dan membuat pertanyaan serta menyelesaikannya secara mandiri. Pada tahap I sampai III siswa terbiasa mengerjakan berbagai bentuk soal sehingga kemampuan mengaplikasikan konsep dalam pemecahan masalah muncul. Akan tetapi pada tahap yang tidak terlaksana dengan optimal adalah tahap practise with process karena pada tahap ini masih sedikit siswa yang berani mengeluarkan idenya sendiri untuk memecahkan permasalahan pada tahap ini, ketika diberi permasalahan beberapa siswa langsung bertanya kemudian pada tahap ini siswa belum bisa memeriksa kembali hasil dengan menggunakan strategi lain dan secara berkelompok sehingga masih perlu bantuan dan bimbingan dari guru. Kemudian pada tahap working with real problem siswa belum bisa menyelesaikan ataupun memecahkan masalah dengan secara mandiri sehingga selama tahap ini berlangsung sebanyak tiga kali pertemuan siswa selalu menyelesaikan permasalahan dengan cara berdiskusi. Hal ini juga sejalan dengan Munandar (2009:174) yang mengemukakan bahwa "semua siswa di dalam kelas dapat dilibatkan dalam kegiatan tingkat I dan II, tetapi hanya beberapa yang dapat melanjutkan ketahap penerapan (tingkat III). Sehingga pada tahap ini 
dalam memecahkan dan mencari penyelesaian masalah siswa belum bisa secara mandiri atau individu.

b. Kemampuan Pemecahan Masalah Siswa

Untuk mengetahui kemampuan pemecahan masalah siswa dengan model Treffinger, siswa dituntut untuk menyelesaikan masalah yang ada pada LAS pada pertemuan pertama, kedua, dan ketiga. Setelah mengikuti pembelajaran dengan model Treffinger dari pertemuan pertama sampai dengan pertemuan ketiga, pada pertemuan keempat siswa diberikan soal tes untuk melihat kemampuan pemecahan masalah siswa berdasarkan teori Treffinger (Pamalato,2005:19) model yang dikembangkan olehnya merupakan model yang bersifat Developmental dan lebih mengutamakan proses. Model pembelajaran ini dapat membantu siswa dalam menguasai konsep-konsep materi yang diajarkan, serta memberika kesmpatan kepada siswa untuk menggali potensi kemampuan yang dimiliki termasuk kemampuan pemecahan masalah dalam menemukan pemecahan masalah yang dihadapinya yang melibatkan proses berfikir.

Berdasarkan hasil analisis data tes diperoleh bahwa nilai ratarata hasil tes siswa terendah pada indikator memeriksa kembali. Namun dari tabel 4.3 dapat dilihat untuk soal nomor tiga indikator pertama sebanyak $67 \%$ siswa tidak mengidentifikasi unsur-unsur yang diketahui dan ditanyakan secara lengkap dan benar. Hal ini dikarenakan masih banyak siswa yang bingung karena apa yang diketahui dari soal terlalu panjang dan beberapa siswa yang menulis tetapi tidak lengkap. Untuk soal nomor satu ketika tes berlangsung banyak siswa yang masih bingung dan tidak melakukan pengecekan. Didapat dari lembar jawaban siswa terutama untuk soal nomor satu masih banyak siswa yang tidak memeriksa kembali hasil sehingga indikator keempat belum tercapai belum tercapai. Hal ini didukung oleh hasil penelitian Agnesa (2011) yang melaporkan bahwa indikator 
kemampuan pemecahan masalah yang paling rendah dicapai siswa adalah memeriksa kembali (looking back). Siswa tidak terbiasa memeriksa kembali jawaban mereka sehingga terdapat kesalahankesalahan sederhana seperti tidak menuliskan satuan yang menyebabkan kehilangan point dalam menjawab soal-soal yang diajukan. Jadi dengan kata lain dalam melakukan pengecekan kembali atau memeriksa hasil lebih sulit dibandingkan merencanakan penyelesaian dan menyelesaikan masalah sesuai dengan rencana sehingga banyak siswa yang masih tidak melakukan pemeriksaan kembali hasil yang diperoleh. Pada soal nomor tiga masih banyak siswa yang tidak mengidentifikasi unsur-unsur yang diketahui dan ditanyakan. Hal ini dikarenakan masih banyak siswa yang bingung karena apa yang diketahui dari soal terlalu panjang dan ada beberapa siswa yang menulis tetapi tidak lengkap.

Dengan demikian berdasarkan hasil yang diperoleh dapat disimpulkan bahwa kemampuan pemecahan masalah siswa setelah diterapkannya model pembelajaran Treffinger dalam kategori baik. Hal ini sejalan dengan hasil penelitian Darminto (2010) yang mengatakan bahwa model pembelajaran Treffinger sangat mungkin diterapkan dalam pembelajaran matematika dalam rangka meningkatkan kemampuan keatif atau kreativitas dan kemampuan pemecahan masalah.

Menurut Romita (2012) model pembelajaran Treffinger merupakan salah satu model pembelajaran yang berbasis pada pemecahan masalah secara kreatif dimana siswa mengumpulkan informasi yang ada, mencari masalah, mencari jawaban,membuat hipotesis menguji, menyempurnakan, dan mengkomunikasikan hasil yang didapat. Pada tahap-tahap model pembelajaran Treffinger ini di tahap pertama yaitu basic tool siswa akan dihadapkan soal-soal terbuka untuk menggali keterampilan berfikir divergen siswa dan 
teknik-teknik kreatif siswa dalam memecahkan masalah, pada tahap kedua practisse with process siswa akan dihadapkan soal-soal yang complicated untuk menerapkan keterampilan yang dipelajarai siswa pada tahap basic tool dan menambah wawasan siswa untuk berfikir bagaimana memecahkan masalah yang dipelajari dan terakhir pada tahap working with real problem siswa akan menerapkan keterammpilan pada tahap-tahap sebelumnya dimana siswa akan mengkonstruk sendiri ide masalah serta merumuskan ide penyelesaian. Pada tahap ketiga ini siswa akan menggunakan teknik-teknik pemecahan masalah. Dalam hal ini siswa akan terlibat aktif dan rasa ingin mendalami bahan yang telah dipelajari. Dengan kreativitas yang dimiliki siswa berarti siswa mampu menggali potensinya dalam daya cipta, menemukan gagasan, serta menemukan pemecahan masalah yang dihadapinya yang melibatkan proses berfikir. Dengan demikian pembelajaran dengan menggunakan model Treffinger dapat menumbuhkan dan meningkatkan kemampuan pemecahan masalah matematika siswa, mengarahkan siswa untuk berfikir secara logis tentang hubungan antar konsep dan situasi dalam permasalahan yang diberikan serta menghargai keberagaman berfikir yang timbul selama proses pemechan masalah berlangsung.

\section{KESIMPULAN}

Berdasarkan hasil analisis data pada bagian sebelumnya, maka dapat disimpulkan bahwa:

1. Penerapan Model Pembelajaran Treffinger pada pembelajaran matematika dikelas VIII.7 SMP Negeri 9 Palembang berlangsung dengan baik. Tahap-tahap pembelajaran yang dilalui pada model pembelajaran Treffinger tersebut meliputi Basic Tool, Practise With Process, dan Working With Real Problem. Semua itu pada umumnya terlaksana. 
2. Persentase siswa dengan nilai minimal 80 dari hasil tes dengan soal pemecahan masalah menggunakan model pembelajaran Treffinger adalah 86.67\%. Ini menunjukkan kemampuan pemecahan masalah siswa di SMP Negeri 9 tergolong baik

Adapun beberapa saran yang dapat peneliti berikan adalah sebagai berikut:

1. Bagi guru, model pembelajaran Treffinger dapat dijadikan sebagai alternatif yang dapat diterapkan dalam proses pembelajaran untuk mengetahui kemampuan pemecahan masalah siswa.

2. Peneliti selanjutnya yang ingin mengembangkan penelitian ini dalam pembuatan rencana pembelajaran dengan model pembelajaran Treffinger agar memperhatikan pembagian waktu untuk tiap-tiap tahapan yang ada pada model pembelajaran Treffinger.

\section{DAFTAR PUSTAKA}

Agnesa, Tia. 2011. Peningkatan Kemampuan Pemecahan Masalah Matematis Siswa SMP Melalui Pembelajaran Berbasis Masalah Open-Ended. Bandung: Universitas Pendidikan Indonesia

Anggraini, Lela.,Siroj A. Rusdy, dan Ratu Ilma.2010. Penerapan Model Pembelajaran Investigasi Kelompok Untuk Meningkatkan Kemampuan Pemecahan Masalah Matematika Siswa Kelas Viii-4 Smp Negeri 27 Palembang. Jurnal Pendidikan Matematika, Volume 4.No.1, Juni 2010

Darminto, Priyo B. 2011. Peningkatan Kreativitas Dan Pemecahan Masalah Bagi Calon Guru Matematika Melalui Pembelajaran Model Treffinger. Jurnal Nasional Matematika dan Pendidikan Matematika. Yogyakarta: Universitas Negeri Yogyakarta

Departemen Pendidikan Nasional. 2008. Kurikulum Tingkat Satuan Pendidikan 2006. Jakarta : Depdiknas.

Ekawati,Lidiaya. 2010. Pengaruh Pembelajaran Terpadu Model Nested Terhadap Kemampuan Pemecahan Masalah. Universitas Islam Negeri Jakarta

NCTM. 2000. Principles and Standards for School Mathematics. Reston: NCTM 
Pomalato, Sarson Waliyatimas Dj. 2005. Pengaruh Model Treffinger dalam Pembelajaran Matematika dalam Mengembangkan Kemampuan Kreatif dan Kemampuan Pemecahan Masalah Matematika Siswa. Bandung: Universitas Pendidikan Bandung

Romita.2012.Pengaruh Penerapan Model Pembelajaran Treffinger Terhadap Kemampuan Pemecahan Matematika Siswa MTS Hasaniah Pekabaru. Universitas Islam Negeri Sultan Syarif Karim Riau

Teti, Rohaeti.2013. Penerapan Model Treffinger Pada Pembelajaran Matematika Untuk Meningkatkan Kemampuan Berpikir Kreatif siswa SMP. Jurnal Online Pendidikan Matematika Kontemporer Vol. 1 No.1. http://journal.fpmipa.upi.edu/index.php/jopmk/article/view/41. Diakses tanggal 27 Januari 2015

Yuanari, Novita. 2011. Penerapan Strategi TTW (Think-Talk-Write) Sebagai Upaya Meningkatkan Kemampuan Pemecahan Masalah Dan Disposisi Matematis Siswa Kelas VIII SMP N 5 Wates Kulonprogo. Universitas Negeri Yogyakarta 